Al-Khwarizmi: Jurnal Pendidikan Matematika dan Ilmu Pengetahuan Alam

Oktober-2020, Vol.8, No.2, hal.123-132

$\operatorname{ISSN}(P):$ 2337-7666; ISSN(E):2541-6499

https://ejournal.iainpalopo.ac.id/index.php/al-khwarizmi

DOI: http://dx.doi.org/10.24256/ipmipa.v8i2.1177

\title{
Kesalahan Siswa dalam Menyelesaikan Soal Kemampuan Spasial Matematis
}

\author{
Citra Utami \\ Pendidikan Matematika, Departemen MIPA, STKIP Singkawang \\ JI STKIP Kelurahan Naram Kecamatan Singkawang Utara \\ Kota Singkawang 79151 Kalimantan Barat \\ Email: citrautami1990@mail.com
}

Article History:

Received: 30-01-2020; Received in Revised: 09-06-2020; Accepted: 20-08-2020

\begin{abstract}
The mistake in solving the problems are important to know. One of the most important skills, especially in the field of geometry, is mathematical spatial ability. Therefore, this study aims to determine the form of student mistakes in solving mathematical spatial ability questions. This research is descriptive qualitative. The instrument used was a test of students' mathematical spatial abilities. The subjects in this study were students of class XA who attended one of the Madrasa Aliyah Swasta in Singkawang, totaling 30 people. The results showed that the form of the mistake made by students in solving problems included: 1) misconceptions consisted of errors in determining the position of the image, errors in drawing, errors in determining the formula for the distance from the point to the line, and errors in determining the formula for the distance from the point to the field; and 2) operating errors consist of errors in the calculation process.
\end{abstract}

Keywords: Mathematical Spatial Ability; The Mistake in Mathematic.

\begin{abstract}
Abstrak
Kesalahan dalam menyelesaikan soal merupakan suatu informasi yang penting untuk diketahui. Salah satu kemampuan yang penting dikuasai khususnya pada bidang geometri adalah kemampuan spasial matematis. Oleh karena itu, penelitian ini bertujuan untuk mengetahui bentuk kesalahan siswa dalam menyelesaikan soal kemampuan spasial matematis. Penelitian ini bersifat deskriptif kualitatif. Instrumen yang digunakan berupa tes kemampuan spasial matematis siswa. Subjek dalam penelitian ini adalah siswa kelas XA yang bersekolah di salah satu Madrasa Aliyah Swasta di Singkawang yang berjumlah 30 orang. Hasil penelitian menunjukkan bahwa bentuk kesalahan yang dilakukan siswa dalam menyelesaikan soal meliputi: 1) kesalahan konsep terdiri dari kesalahan dalam menentukan posisi gambar, kesalahan dalam menggambar, kesalahan dalam menentukan rumus jarak titik ke garis, dan kesalahan dalam menentukan rumus jarak titik ke bidang; dan 2) kesalahan operasi terdiri dari kesalahan dalam melakukan proses perhitungan.
\end{abstract}

Kata Kunci: Kemampuan Spasial Matematis; Kesalahan dalam Matematika. 


\section{Pendahuluan}

Matematika merupakan ilmu berhitung yang memuat bahasa simbol, antar konsep saling berkaitan, dan pola berpikir yang jelas. Salah satu objek dalam matematika adalah objek langsung. Objek langsung matematika terdiri dari fakta, keterampilan/operasi, konsep, dan prinsip.

Berdasarkan objek tersebut, kesalahan dalam menyelesaikan soal matematika dapat dilihat dari kesalahan fakta, kesalahan keterampilan/operasi, kesalahan konsep, dan kesalahan prinsip. Sejalan dengan Hidayat, Sugiarto, \& Pramesti mengelompokkan kesalahan dalam mengerjakan soal matematika menjadi empat, yaitu kesalahan fakta, kesalahan konsep, kesalahan operasi, dan kesalahan prinsip. ${ }^{1}$

Kesalahan dalam menyelesaikan soal matematika menjadi suatu informasi yang penting untuk diketahui agar letak kesalahan atau ketidakpahaman dalam mengerjakan soal matematika dapat terlihat kemudian diatasi. Soal matematika memuat beragam jenis materi dan kemampuan sesuai keinginan pembuat soal untuk mengukur materi atau kemampuan tertentu. Satu diantara materi yang biasa diukur dalam soal matematika adalah geometri.

Geometri merupakan satu dari cabang ilmu yang ada di matematika. Seperti yang telah diketahui bahwa matematika merupakan materi yang penting karena ada pada tiap jenjang pendidikan bahkan dalam kehidupan sehari-hari. Sesuai dengan NCTM yang menyatakan bahwa satu diantara lima standar isi dalam matematika adalah geometri. ${ }^{2}$ Hal ini menunjukkan pentingnya materi geometri. Namun faktanya penguasaan siswa terhadap materi geometri masih kurang. Sejalan dengan hasil penelitian Ozerem yang menunjukkan bahwa siswa sekolah menengah kelas 7 memiliki sejumlah kesalahpahaman, kurangnya latar belakang pengetahuan, alasan dan kesalahan operasi dasar pada materi geometri. ${ }^{3}$ Untuk menindaklanjuti hal ini, pentingnya mengetahui kesalahan siswa dalam menyelesaikan soal geometri. Salah satu kemampuan yang dominan pada geometri adalah kemampuan spasial matematis.

Kemampuan spasial matematis merupakan kemampuan yang focus pada bidang geometri. Menurut Wahyudin kemampuan spasial adalah kemampuan menyatakan kedudukan antar unsur-unsur suatu bangun ruang,

1 Badi Rahmad Hidayat, Bambang Sugiarto, and Getut Pramesti, "Analisis Kesalahan Siswa Dalam Menyelesaikan Soal Pada Materi Ruang Dimensi Tiga Ditinjau Dari Gaya Kognitif Siswa," Jurnal Pendidikan Matematika Solusi 1, no. 1 (2013): 39-46.

2 National Council of Teachers of Mathematics, Principles and Standards for School Mathematics (Reston, VA: National Council of Teachers of Mathematics, 2000), http://archive.org/details/principlesstanda00nati.

3 Ayşen Özerem, "Misconceptions in Geometry and Suggested Solutions for Seventh Grade Students," Procedia-Social and Behavioral Sciences 55 (2012): 720-729. 
mengidentifikasi gambar-gambar geometri, mengklasifikasi gambar-gambar geometri serta membayangkan bentuk atau posisi suatu objek geometri yang dipandang dari sudut pandang tertentu. ${ }^{4}$ Sejalan dengan Lestari dan Yudhanegara menyatakan bahwa kemampuan spasial adalah kemampuan membayangkan, membandingkan, menduga, menentukan, mengonstruksi, memrepresentasikan, dan menemukan informasi dari stimulus visual dalam konteks ruangan. ${ }^{5}$ Berdasarkan hal tersebut, kemampuan spasial matematis menekankan pada bidang geometri dan penting untuk dikuasai siswa. Pentingnya kemampuan spasial menuntut siswa untuk memiliki kemampuan spasial matematis yang baik. Karena dalam belajar matematika tidak lepas dari geometri, sehingga dengan kemampuan spasial yang baik, kemampuan matematis juga menjadi baik, khususnya di bidang geometri.

Beberapa hasil penelitian tentang kesalahan siswa dalam menyelesaikan soal geometri diantaranya hasil penelitian Ikhsan dan Juandi dan penelitian Kurniasari menunjukkan bahwa siswa mengalami kesalahan dalam memahami konsep jarak titik ke garis, dan melakukan kesalahan prosedur yaitu kesalahan atau kurang teliti saat proses perhitungan ${ }^{67}$. Selain dapat mengetahui kesalahan yang dilakukan siswa dalam menyelesaikan soal, soal matematika juga dapat digunakan untuk mengetahui kemampuan yang dimiliki. Oleh karena itu, dengan adanya penelitian ini dapat membantu guru maupun siswa memperoleh informasi mengenai kesalahan-kesalahan yang mungkin terjadi dan kemampuan yang dimiliki siswa pada materi geometri.

Berdasarkan uraian yang telah dipaparkan, masalah dalam penelitian ini yaitu apa saja bentuk kesalahan siswa dalam menyelesaikan soal kemampuan spasial matematis pada materi dimensi tiga? Adapun tujuan tujuan dalam penelitian ini yaitu untuk mengetahui bentuk kesalahan siswa dalam menyelesaikan soal kemampuan spasial matematis pada materi dimensi tiga.

\section{Metode}

Penelitian ini menggunakan metode deskriptif kualitatif. Subjek dalam penelitian ini berjumlah 30 siswa kelas X di Madrasah Aliyah Swasta di

4 Zarkasyi Wahyudin, Penelitian Pendidikan Matematika (Bandung: PT Refika Aditama, 2015).

${ }^{5}$ K. E. Lestari and M. R. Yudhanegara, "Penelitian Pendidikan Matematika (Panduan Praktis Menyusun Skripsi)" (PhD Thesis, Tesis, dan Laporan Penelitian dengan Pendekatan Kuantitatif, Kualitatif, dan ..., 2017).

${ }^{6}$ Roskawati Roskawati, M. Ikhsan, and Dadang Juandi, "Analisis Penguasaan Siswa Sekolah Menengah Atas Pada Materi Geometri," Jurnal Didaktik Matematika 2, no. 1 (2015).

${ }^{7}$ Ika Kurniasari, "Identifikasi Kesalahan Siswa Dalam Menyelesaikan Soal Geometri Materi Dimensi Tiga Kelas XI IPA SMA," in Prosiding Seminar Nasional Matematika Dan Pendidikan Matematika FMIPA UNY, vol. 329, 2013. 
Singkawang, Kalimantan Barat. Teknik pengumpulan data yang digunakan adalah teknik pengukuran. Teknik pengukuran yaitu suatu teknik untuk memperoleh data kuantitatif menggunakan alat tes. Instrumen yang digunakan untuk memperoleh data penelitian yaitu berupa soal tes kemampuan spasial matematis berbentuk essay sebanyak 3 soal pada materi dimensi tiga. Tiap nomor soal memuat satu indikator kemampuan spasial matematis, yaitu soal nomor satu memuat indikator pertama, soal nomor dua memuat indikator kedua, dan soal nomor tiga memuat indikator ketiga. Soal tes telah dilakukan validasi isi (dua rekan sejawat/dosen dan 1 guru) dan diujicobakan di sekolah. Setelah layak digunakan, soal tes diberikan ke subjek penelitian.

Indikator kemampuan spasial yang digunakan adalah indikator yang dikembangkan oleh Maier yaitu:

1. Orientasi (kemampuan untuk memprediksi visual bangun ruang jika dilihat dari berbagai sudut pandang),

2. Visualisasi (kemampuan dalam memvisualisasikan bangun ruang menjadi jaring-jaring yang tepat atau sebaliknya),

3. Relasi (kemampuan dalam menghubungkan bagian-bagian visual dalam sisi bangun ruang).

Pemberian tes dilakukan terhadap 30 siswa. Dari hasil jawaban tersebut, kemudian dikoreksi, mendata bentuk kesalahan yang telah dilakukan siswa (setelah didata, jika terdapat bentuk kesalahan yang sama dilakukan beberapa siswa, maka dihitung 1 bentuk kesalahan, diambil salah satu jawaban siswa tersebut sebagai subjek yang dideskripsikan bentuk kesalahannya), mendeskripsikan, dan menyimpulkan.

\section{Hasil dan Diskusi}

Hasil analisis data yang diperoleh menunjukkan beberapa kesalahan yang dilakukan siswa dalam menyelesaikan soal kemampuan spasial matematis. Untuk soal nomor 1 dengan indikator orientasi, siswa diberikan soal berupa gambar sebuah kubus dengan beberapa bagian yang dihitamkan (sisi atas gambar catur, sisi kanan segitiga separuh hitam, separuh putih, dan sisi depan titik hitam kecil). Siswa diminta untuk menggambarkan posisi kubus jika kubus tersebut digulingkan satu kali ke kiri. Cuplikan jawaban siswa pada soal nomor 1 disajikan pada Gambar 1 . 

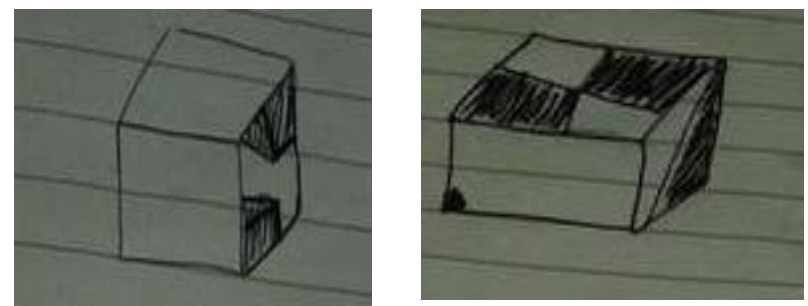

Gambar 1. Cuplikan Jawaban Siswa pada Soal Nomor 1.

Berdasarkan Gambar 1 terlihat siswa menggambar kubus dengan posisi bagian yang dihitamkan tidak sesuai jawaban yang benar dan gambar yang diberikan hanya ada sisi yang catur. Siswa lain ada yang menggambar lengkap, namun posisi yang digambarkan kurang tepat dan beberapa posisi lain dengan kesalahan yang sama, yaitu salah menempatkan posisi. Hal ini diasumsikan siswa tidak dapat membayangkan letak posisi dari suatu benda jika dilihat dari berbagai sudut pandang. kesalahan yang dilakukan siswa termasuk kesalahan konsep karena siswa tidak memahami letak posisi yang benar (salah dalam menentukan posisi gambar) walaupun dari sudut pandang yang berbeda. Sejalan dengan hasil penelitian Kurniasari menunjukkan bahwa dalam menyelesaikan soal geometri, siswa melakukan kesalahan konsep. ${ }^{8}$
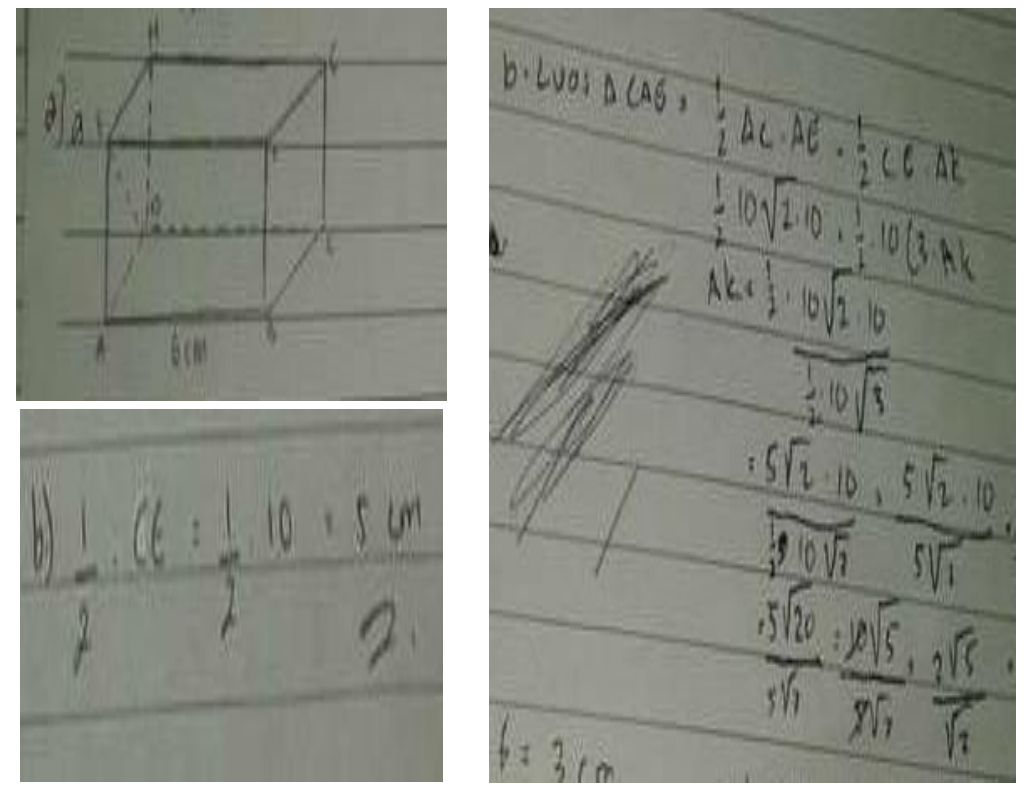

Gambar 2. Cuplikan Jawaban Siswa Pada Soal Nomor 2

Untuk soal nomor 2 dengan indikator visualisasi, siswa diberikan sebuah bangun ruang lengkap dengan ukurannya, diminta menggambarkan salah satu bidang yang memuat salah satu titik sudut tertentu dan 
diagonalnya kemudian menghitung jarak dari titik tersebut ke garis diagonalnya. Cuplikan jawaban siswa pada soal nomor 2 disajikan pada Gambar 2. Berdasarkan Gambar 2, jawaban yang siswa berikan, siswa salah dalam menggambar garis diagonal yang diminta. Sehingga untuk perintah berikutnya, siswa juga menjawab dengan salah. Jika dilihat dari perintahnya, soal mengenai diagonal ruang, namun yang dibuat siswa bukan diagonal ruang melainkan diagonal sisi (salah dalam menggambar).

Selanjutnya siswa diminta untuk menghitung jarak dari titik tersebut ke diagonal ruangnya. Berdasarkan Gambar 2 dapat dilihat bahwa jawaban yang siswa berikan, siswa keliru dalam menentukan rumus yang seharusnya digunakan. Dari jawaban yang siswa berikan, dapat dilihat bahwa siswa tidak paham konsep dalam menentukan suatu jarak, yang dihitung adalah sebuah garis lurus yang tegak lurus. Kesalahan berikutnya adalah siswa kurang teliti dalam melakukan prosedur atau operasi. Saat menentukan rumus yang digunakan, dan menentukan garis mana yang bertindak sebagai jarak, siswa sudah benar menggunakannya, namun keliru saat melakukan prosedurnya sehingga jawaban yang diberikan jadi kurang tepat. Sejalan dengan hasil penelitian Ikhsan dan Juandi dan hasil penelitian Kurniasari yang menunjukkan bahwa siswa mengalami kesalahan dalam memahami konsep jarak titik ke garis dan melakukan kesalahan prosedur yaitu melakukan kesalahan atau kurang teliti saat proses perhitungan. ${ }^{9} 10$

Kesalahan lain yang terdapat pada soal nomor 2 adalah siswa membuat gambar tidak sesuai dengan perintah soal. Siswa tidak dapat membuat gambar yang sesuai dari perintah soal dalam bentuk kata-kata. Namun, saat mengerjakan perintah berikutnya yang menentukan jarak titik ke garis diagonal tersebut, siswa dapat mengerjakannya. Hal ini diasumsikan karena pada dasarnya siswa menghapal/mengingat rumus, bukan memahami. Sehingga saat menemukan soal seperti ini, siswa ingat dan tahu harus menggunakan rumus yang mana, namun saat diminta menggambar, siswa tidak paham. Siswa lainnya pada soal nomor 2 dapat menggambar bidang yang diinginkan namun kurang lengkap. Sesuai perintah soal, siswa tersebut dapat menggambar bidang yang diinginkan, namun tidak dapat menggambarkan jarak titik ke garis, sehingga saat menentukan jarak titik ke garis, siswa tidak bisa melakukannya. Diasumsikan siswa mungkin lupa atau tidak paham bahwa konsep jarak adalah suatu garis yang tegak lurus. Namun siswa tersebut justru berpikir bahwa jaraknya adalah setengah dari garis diagonal tersebut, sehingga jawaban yang diberikan salah.

${ }^{9}$ Roskawati, Ikhsan, and Juandi, "Analisis Penguasaan Siswa Sekolah Menengah Atas Pada Materi Geometri."

10 Kurniasari, "Identifikasi Kesalahan Siswa Dalam Menyelesaikan Soal Geometri Materi Dimensi Tiga Kelas XI IPA SMA.” 

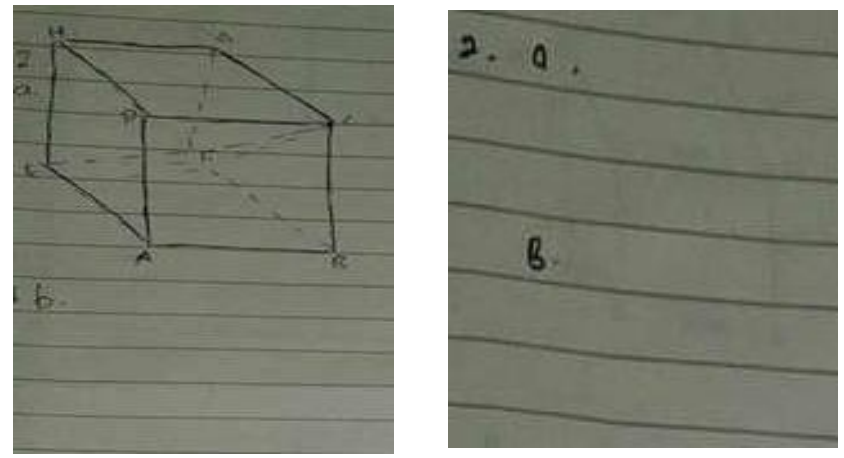

Gambar 3. Cuplikan Kesalahan Siswa Pada Soal Nomor 2.

Siswa lainnya, hanya menggambarkan kubus tanpa memperdulikan perintah berikutnya. Cuplikan kesalahan siswa ini disajikan pada Gambar 3. Berdasarkan Gambar 3, dapat diasumsikan siswa tidak memahami masalah/soal dengan baik sehingga apa yang dikerjakan tidak sesuai perintah soal. Kurangnya siswa dalam memahami soal artinya siswa melakukan kesalahan konsep.

Sejalan dengan hasil penelitian Satoto, Sutarto \& Pujiasti, hasil penelitian Wildani, dan hasil penelitian Wijaya, Van Den Heuvel-Panhuizen, Doorman, \& Robitzsch yang menunjukkan bahwa terdapat beberapa siswa yang melakukan kesalahan dalam memahami masalah yang disajikan 111213 . Selanjutnya siswa tidak memahami konsep yang digunakan untuk menghitung jarak titik ke garis sehingga tidak mengerjakan apapun untuk mencoba menghitung jarak titik ke garis. Bahkan ada siswa tidak menjawab sama sekali soal nomor 2 (disajikan pada Gambar 3).

Untuk soal nomor 3 dengan indikator relasi, siswa diberikan sebuah kubus lengkap dengan ukurannya, dan sebuah titik yang berada di pertengahan salah satu rusuknya. Siswa diminta untuk menggambar dan menentukan jarak dari salah satu titik sudut ke titik tengah tersebut, menentukan jarak titik ke garis, dan jarak titik ke bidang. Jawaban yang siswa berikan, siswa hanya bisa memberikan gambar kubus tanpa ilustrasi permasalahan yang diberikan. Ada beberapa yang hanya menggambar kubus tanpa diberi nama. Bahkan ada beberapa siswa yang menggambar kubus tapi berbentuk seperti balok. Hal ini diasumsikan karena siswa menganggap gambar tidak penting, atau menyepelekan gambar yang artinya siswa melakukan kesalahan dalam memahami soal. Padahal dengan bantuan

11 Matematika Unnes Seto Satoto, Matematika Unnes Hery Sutarto, and Matematika Unnes Emi Pujiastuti, "Analisis Kesalahan Hasil Belajar Siswa Dalam Menyelesaikan Soal Dengan Prosedur Newman," Unnes Journal of Mathematics Education 1, no. 2 (2012): 1-7.

12 Junaidah Wildani, "Analisis Kesalahan Siswa Dalam Menyelesaikan Masalah Aljabar," Unisda Journal of Mathematics and Computer Science (UJMC) 4, no. 1 (2018): 9-18.

${ }^{13}$ Ariyadi Wijaya et al., "Difficulties in Solving Context-Based PISA Mathematics Tasks: An Analysis of Students' Errors," The Mathematics Enthusiast11, no. 3 (2014): 555-584. 
gambar, dapat mempermudah penyelesaian soal khususnya materi dimensi tiga bagi siswa yang mengalami kesulitan dalam membayangkan. Sejalan dengan hasil penelitian Safitri \& Khotimah yang menunjukkan bahwa beberapa kesalahan yang dilakukan siswa dalam menyelesaikan soal, diantaranya adalah kesalahan dalam memahami soal dan kesalahan keterampilan. ${ }^{14}$

Kesalahan lain yang ditemukan pada soal nomor 3 adalah kesalahan konsep. Siswa tidak dapat menentukan rumus yang digunakan untuk menghitung jarak titik ke garis, dan jarak titik ke bidang. Diasumsikan siswa tidak paham bahwa konsep jarak adalah tegak lurus, sehingga keliru dalam mengerjakannya. Sejalan dengan hasil penelitian Sunarsi yang menunjukkan bahwa siswa melakukan kesalahan dalam menggunakan dan menerapkan rumus yang diperlukan karena siswa tidak teliti dan tidak memahami maksud soal. ${ }^{12}$ Selanjutnya kesalahan yang dilakukan siswa pada soal nomor 3 adalah siswa dapat menuliskan rumus tapi tidak dapat membuat gambar. Diasumsikan siswa hanya menghapalkan rumus tanpa memahami konsep apa yang digunakan untuk menemukan rumus tersebut. Padahal memahami konsep itu lebih baik daripada sekedar menghafal rumus. Sesuai pendapat Piaget dalam buku yang ditulis Hergenhahn and Olson jika pemahaman konsep baik dan masuk ke dalam memori jangka lama di otak akibatnya walaupun pelajaran telah lama dilalui, konsepnya tetap diingat dan diketahui siswa. ${ }^{15}$ Jadi siswa bukan hanya sekedar menghapal rumus, tapi harus paham konsep. Selain itu, sama seperti soal nomor 2, siswa melakukan kesalahan operasi. Siswa benar dalam menentukan rumus yang akan digunakan, namun terjadi kekeliruan saat proses pengerjaannya sehingga menghasilkan jawaban yang kurang tepat.

Dari ketiga soal tersebut, juga ditemukan beberapa siswa yang memberikan jawaban kosong tanpa menuliskan apapun (tidak diketahui). Sehingga tidak dapat diketahui kesalahan apa yang dilakukan oleh siswasiswa tersebut. Secara keseluruhan dalam penelitian ini, kesalahan yang dilakukan oleh siswa ada dua jenis, yaitu kesalahan konsep dan kesalahan operasi/prosedur. Sejalan dengan hasil penelitian Hamdani yang menunjukkan bahwa siswa melakukan kesalahan konsep, kesalahan prosedur, dan kesalahan kecerobohan ${ }^{16}$. Berdasarkan hasil bentuk-bentuk kesalahan yang telah ditemukan, dapat disimpulkan bahwa kemampuan

14 Marlina Wulan Safitri and Rita Pramujiyanti Khotimah, "Kesalahan Siswa Dalam Menyelesaikan Soal-Soal Trigonometri Kelas XI SMK Muhammadiyah Kartasura Tahun 2016/2017" (PhD Thesis, Universitas Muhammadiyah Surakarta, 2017).

15 B. R. Hergenhahn and Matthew H. Olson, "Theories of Learning (Teori Belajar Edisi Ketujuh)," Terjemahan Oleh Tri Wibowo BS, 2008.

16 Yan Bistari Hamdani, "Analisis Kesalahan Dalam Menyelesaikan Soal Luas Permukaan Serta Volume Bangun Ruang Sisi Datar Di SMP," Jurnal UNTAN, 2012, 45-56. 
spasial matematis siswa masih rendah. Karena kemampuan spasial matematis adalah kemampuan yang berhubungan dengan objek geometri. Semakin banyak kesalahan yang dilakukan siswa, semakin rendah pula penguasaan kemampuan spasial matematisnya.

\section{Kesimpulan}

Artikel ini menunjukkan bahwa kemampuan spasial matematis siswa kelas X di salah satu Madrasah Aliyah Swasta di Singkawang masih rendah. Terdapat dua bentuk kesalahan dalam menyelesaikan soal kemampuan spasial matematis yaitu kesalahan konsep dan kesalahan operasi/prosedur. Kesalahan konsep yang dilakukan siswa diantaranya siswa melakukan kesalahan dalam menggambar, kesalahan dalam menentukan posisi gambar, kesalahan dalam memahami soal sehingga tidak dapat membuat gambar, kesalahan dalam menentukan jarak titik ke garis, dan kesalahan dalam menentukan jarak titik ke bidang. Selain itu siswa juga melakukan kesalahan operasi, artinya siswa dapat memahami konsep atau menggunakan rumus yang tepat namun melakukan kekeliruan dalam proses perhitungan dan pengerjaannya yang dapat disebabkan oleh kurangnya ketelitian dalam pengerjaan soal.

Berdasarkan hasil penelitian ini, diharapkan peneliti selanjutnya dapat menemukan cara untuk mengurangi kesalahan yang dilakukan siswa dalam menyelesaikan soal kemampuan spasial matematis pada materi dimensi tiga. Selain itu, mearik juha untuk mengkaji faktor penyebab siswa melakukan kesalahan-kesalahan dalam menyelesaikan soal.

\section{Daftar Pustaka}

Hamdani, Yan Bistari. "Analisis Kesalahan Dalam Menyelesaikan Soal Luas Permukaan Serta Volume Bangun Ruang Sisi Datar Di SMP." Jurnal UNTAN, 2012, 45-56.

Hergenhahn, B. R., and Matthew H. Olson. "Theories of Learning (Teori Belajar Edisi Ketujuh)." Terjemahan Oleh Tri Wibowo BS, 2008.

Hidayat, Badi Rahmad, Bambang Sugiarto, and Getut Pramesti. "Analisis Kesalahan Siswa Dalam Menyelesaikan Soal Pada Materi Ruang Dimensi Tiga Ditinjau Dari Gaya Kognitif Siswa." Jurnal Pendidikan Matematika Solusi 1, no. 1 (2013): 39-46.

Kurniasari, Ika. "Identifikasi Kesalahan Siswa Dalam Menyelesaikan Soal Geometri Materi Dimensi Tiga Kelas XI IPA SMA.” In Prosiding Seminar Nasional Matematika Dan Pendidikan Matematika FMIPA UNY, Vol. 329, 2013.

Lestari, K. E., and M. R. Yudhanegara. "Penelitian Pendidikan Matematika (Panduan Praktis Menyusun Skripsi)." PhD Thesis, Tesis, dan Laporan Penelitian dengan Pendekatan Kuantitatif, Kualitatif, dan ..., 2017. 
National Council of Teachers of Mathematics. Principles and Standards for School Mathematics. Reston, VA: National Council of Teachers of Mathematics, 2000. http://archive.org/details/principlesstanda00nati.

Özerem, Ayșen. "Misconceptions in Geometry and Suggested Solutions for Seventh Grade Students." Procedia-Social and Behavioral Sciences 55 (2012): 720-729.

Roskawati, Roskawati, M. Ikhsan, and Dadang Juandi. "Analisis Penguasaan Siswa Sekolah Menengah Atas Pada Materi Geometri." Jurnal Didaktik Matematika 2, no. 1 (2015).

Safitri, Marlina Wulan, and Rita Pramujiyanti Khotimah. "Kesalahan Siswa Dalam Menyelesaikan Soal-Soal Trigonometri Kelas XI SMK Muhammadiyah Kartasura Tahun 2016/2017." PhD Thesis, Universitas Muhammadiyah Surakarta, 2017.

Seto Satoto, Matematika Unnes, Matematika Unnes Hery Sutarto, and Matematika Unnes Emi Pujiastuti. "Analisis Kesalahan Hasil Belajar Siswa Dalam Menyelesaikan Soal Dengan Prosedur Newman." Unnes Journal of Mathematics Education 1, no. 2 (2012): 1-7.

Wahyudin, Zarkasyi. Penelitian Pendidikan Matematika. Bandung: PT Refika Aditama, 2015.

Wijaya, Ariyadi, Marja van den Heuvel-Panhuizen, Michiel Doorman, and Alexander Robitzsch. "Difficulties in Solving Context-Based PISA Mathematics Tasks: An Analysis of Students' Errors." The Mathematics Enthusiast 11, no. 3 (2014): 555-584.

Wildani, Junaidah. "Analisis Kesalahan Siswa Dalam Menyelesaikan Masalah Aljabar." Unisda Journal of Mathematics and Computer Science (UJMC) 4, no. 1 (2018): 9-18. 